\title{
How business angel groups work: Rejection criteria in investment evaluation
}

\author{
Annalisa Croce \\ Politecnico di Milano, Italy \\ Francesca Tenca \\ Politecnico di Milano, Italy \\ Elisa Ughetto \\ Politecnico di Torino and BRICK, Real Collegio, Italy
}

\begin{abstract}
In this article, we study the decision-making criteria that business angels (BAs) adopt when screening business opportunities in the different assessment phases (pre-screening, screening and due diligence). We exploit an original dataset of 1942 ventures that sought angel investment from 2008 to 2014 from the members of Italian Angels for Growth (IAG). Results have shown that the emphasis that BAs place on rejection criteria and contact channels varies along the three considered stages of the investment process. In particular, we found that business proposals brought to the attention of BAs by venture capitalists are more likely to get through the pre-screening stage, suggesting an important quality certification role played by venture capitalists. Moreover, at the screening stage (in comparison with the pre-screening stage), proposals are rejected more often for reasons related to the characteristics of the entrepreneur and management team and less often for the lack of business innovativeness. Finally, business proposals showing lower levels of profitability are more likely to be rejected after the due diligence.
\end{abstract}

\section{Keywords}

business angels, investment process, rejection criteria

\section{Introduction}

Business angels (BAs) are acknowledged as an important source of new venture funding (Harrison and Mason, 1999; Van Osnabrugge and Robinson, 2000). ${ }^{1}$ However, despite its importance for high potential new ventures, BA financing is still a relatively neglected segment of

\section{Corresponding author:}

Elisa Ughetto, Department of Management and Production Engineering (DIGEP), Politecnico di Torino, Corso Duca degli Abruzzi 24, 10129 Torino, Italy.

Email: elisa.ughetto@polito.it 
entrepreneurial finance compared to venture capital (VC) (Croce et al., 2016; Hellmann and Thiele, 2015; Hellmann et al., 2015). One of the areas in the literature requiring further exploration is the BA investment process, that is, the criteria that BAs employ to assess investment opportunities along the different phases of their decision-making process, with a specific focus on angel groups.

An extensive literature has examined the overall evaluation criteria that are adopted by BAs when undertaking investment decisions (Feeney et al., 1999; Haines et al., 2003; Landström, 1998; Paul et al., 2007) and how these criteria differ from those adopted by VC investors (Hsu et al., 2014; Van Osnabrugge, 2000), without referring to any specific stage of the investment process. Research has examined BA decisions during a single phase of the decision-making process using ex-post questionnaires, real-time methods and verbal protocols (Clark, 2008; Mason and Harrison, 2003; Mason and Rogers, 1997; Mason and Stark, 2004; Maxwell et al., 2011; Mitteness et al., 2012a, 2012b; Smith et al., 2010). Most of this literature has studied BAs acting as individual investors such that limited evidence exists on angel groups (Mitteness et al., 2012a, 2012b). Recently, work by Brush et al. (2012) and Carpentier and Suret (2015) has explored the multistage nature of the BA decision-making process from the initial project submission to the final decision focusing on angel groups.

Angel groups are increasingly transforming the angel market (Mason et al., 2013). A number of advantages are offered to collective investors: first, the sector-specific experience of the group members and the marketing and financial expertise of the group's staff allow investors to select among a pre-screened set of investment opportunities, making it easier to choose the most promising ventures (Paul and Whittam, 2010; Werth and Boeert, 2013). Second, transaction costs are reduced as the burden of due diligence is spread among several investors. Third, angels can pool their capital to make larger investments. Finally, as angels share the risk of investments with other group members, they are able to participate in a wider range of investment opportunities and also invest smaller amounts in single ventures (Kerr et al., 2014; Mason and Botelho, 2016).

The limited evidence concerning the decisions taken at the level of angel groups, rather than individuals, is surprising given the different approaches to investing adopted by groups compared with independent BAs. With respect to independent BAs, angel groups are reported to invest mainly in firms at later stages of development, to apply more complex contracts and to have a more professional approach to screening submitted projects (Carpentier and Suret, 2015; Kerr et al., 2014; Mason and Botelho, 2016; Sohl, 2012). This article aims to contribute to the nascent literature on the decision-making process of angel groups (Brush et al., 2012; Carpentier and Suret, 2015). It analyses the rejection criteria that a prominent Italian BA group (Italian Angels for Growth (IAG)) adopted when evaluating business opportunities throughout the different phases of the investment process. The nature of the IAG data allows us to fully observe the deal flow through the various assessment phases up to the investment decision. To address this aim, we draw upon an original dataset of 1942 ventures that sought angel investment in the period February 2008 to April 2014 from the members of IAG.

Our methodological approach examines the different evaluation stages and specific motivations leading to rejection, rather than acceptance, of proposals. This approach reflects that adopted by Carpentier and Suret (2015); as noted by Maxwell et al. (2011), an analysis of the causes for rejection in the different screening stages constitutes a unique perspective in the literature on BA financing which predominantly focuses upon successful outcomes.

We contribute to the emerging body of knowledge exploring angel groups and investment criteria in different respects. First, the uniqueness and richness of the IAG database allow us to provide fresh evidence on a fine-grained set of motivations underlying the rejection of business proposals, including market potential, business potential, investor's opportunity fit, innovativeness and quality of the entrepreneur/management team for a large sample of applicant ventures using 
multivariate techniques. Second, due to the availability of firm names in the database, we have been able to collect financial accounting information to explore the impact of rejection upon the financial status of the applicant. Finally, we explore the information on the different channels through which the business proposals have been forwarded to the BA group such as VCs, BA networks (BANs), IAG associates, incubators, website and events to offer a comprehensive analysis of the role third-party intermediation plays in angel decisions.

The remainder of the article is organized as follows. Section 'The angel group' illustrates the deal flow at IAG and provides a description of the successful deals and of the types and traits of investing BAs. The following section puts forward some testable hypotheses in the context of the background literature. The section 'Data and methods' introduces the data and provides some relevant descriptive statistics. The section 'Econometric results' describes the main variables used and discusses the results of the empirical analysis. The article finishes with a conclusion and summary of the main arguments.

\section{The angel group}

Founded in 2007 as a non-profit association by nine co-founders, IAG is an Italian BA group headquartered in Milano consisting of 128 members. IAG presents investment opportunities to its members ranging from $€ 300,000$ to $€ 800,000$, in start-ups and young companies (up to 2 million euros in revenues) with high growth potential. ${ }^{2}$ The projects undergo a preliminary assessment which is delegated to internal staff. BAs can then decide independently whether to invest, and the related amounts, in the projects under evaluation. Up until July 2014, IAG screened a deal flow of 2200 business plans of which 100 proposals were selected for funding. The group, through its members and the involvement of other co-investors, has realized equity investments of around $€ 22,500,000$ in 39 investment rounds. Each member contributes an annual fee of $€ 2500$ to the group and voluntarily donates $5 \%$ of the amount invested in each deal. ${ }^{3}$ Each new member must be introduced by a current member and have an investment capability of more than $€ 150,000 .{ }^{4}$

From the 128 group members, $7 \%$ are women; almost $50 \%$ reside in the same region and nearly $40 \%$ in the same city as the angel group's headquarters. On average, they are 55 years old with a mean employment tenure of 26 years. Most have professional working experience in the private equity/investment sectors (60\%) or are engaged in managerial positions (38\%); $45 \%$ have prior or current entrepreneurial experience. Concerning educational background, 53\% hold a Master Degree, $38 \%$ have an MBA and just $7 \%$, a doctorate.

\section{The deal flow}

The funding process at IAG follows three stages: first, pre-screening, where a preliminary assessment of the business proposal is made; second, screening, where a more thorough assessment of the investment opportunity is conducted; and third, due diligence. The initial pre-screening is undertaken by two group analysts who either 'desk reject' a proposal or move it to the next stage. Analysts provide a primary evaluation of the business plan and often have a preliminary interaction with the entrepreneur (to ask for additional materials and clarifications for example). The staff consider whether the business proposal fits with the investment preferences of the group, assessing the sector in which the business operates, the stage of development and the level of funding required. Typically, a poor fit with the group's scope of action exists when submitted projects are too early stage, have a limited focus or the requested amount is below the target threshold of $€ 150,000$. A low growth potential is envisaged when the business/product presented is not or is only marginally scalable or the business plan is not convincing. Nearly $60 \%$ of rejections in the pre-screening phase refer to business proposals showing a poor investor-opportunity fit and a low growth potential. 
Business proposals which progress through the initial pre-screening are sent to all group members through an online platform called 'Proseeder'. In the screening phase, each angel member may investigate the proposal in more detail. If the proposal attracts sufficient interest from at least two members, a meeting with the entrepreneur is organized; entrepreneurs are invited to pitch their projects with a brief presentation and to answer questions raised by interested BAs. IAG members usually ask for more details regarding the management team, the business plan, the company's market and exit strategy and the scalability and innovativeness of the products. A positive evaluation of the entrepreneur is critical to moving the investment process forward.

The proposal is then examined by a Screening Committee, consisting of IAG members who are appointed every 2 years by the Board. If the Screening Committee believes that the venture should be pursued by the group, entrepreneurs are then invited to a second presentation which takes place in front of all IAG members, at the General Assembly, and occurs every 2.5 months. Ventures that generate the greatest interest enter a due diligence process. In that circumstance, every member is given 3 days to evaluate whether to provide a 'soft financial commitment' to invest in the business and has to indicate the amount of money he or she is willing to invest in the deal. If sufficient capital is collected - a minimum threshold of $€ 200,000$ - due diligence is conducted which lasts, on average, 2-4 months. After the due diligence stage, individual members are fully independent in deciding whether to contribute to the investment and the amount invested. If a business gathers a sufficient level of interest from IAG members, a 'champion' of the deal is selected in order to coordinate the investment process with the support of the group.

\section{The investments}

Table 1 shows the distribution of investment by sector and the corresponding amounts. The two most highly represented sectors are Medical/Biotech (45\% of total funding) and Energy (Cleantech) $(15 \%)$, whereas Internet is the second industry for number of investments and the third for investment amount (13\%). Regarding the geographical distribution of the applicant ventures, almost 30\% of the investments are outside Italy (two ventures in the United States, two in the United Kingdom, one in France and one in Israel). Thus, distance does not seem to be a major obstacle for the group.

In Table 2, we illustrate the relationship between the industries where investment occurs and the industry experience of the BA investors - they tend, on average, to invest more in ventures belonging to sectors in which they have experience. This is particularly notable in the Energy and Medical/ Biotech fields that require more specific and technical competence and higher investment funding. Ventures from the Internet, Software and Information and Communication Technologies (ICT) sectors are mostly supported by BAs with fewer technical competences, having a prior background in the Financial Services, Education and Consultancy fields. In general, the heterogeneity of coinvestor industry experiences, captured by the heterogeneity index, is high for all the considered industries, meaning that BAs lacking specific expertise in a particular sector are able to rely on expert colleagues who work in such industries. The table also suggests that the largest majority of investors have experience in the Financial Services fields $(22.31 \%)$, followed by the Manufacturing $(13.05 \%)$ and Health (8.57\%) sectors.

In Table 3, we illustrate the relationship between the educational background of BA investors (in terms of degree) and the investment industry. A business degree is most common across all industries; most investors have business and administration (26.74\%), engineering (16.86\%) and law degrees $(14.53 \%)$. Ventures belonging to the Software sector are equally attractive to angels with a degree in business, engineering and physics (33\%). Data suggest that those holding an engineering degree invest more, on average, in the Software (33\%) and ICT (20\%) sectors, compared to the Medical/Biotech (15\%) and Energy (16\%) industries. Those with a degree in physics invest more, on average, in ICT (21\%) and Software (33\%) sectors, followed by Biotech (15\%). Conversely, BAs 
Table I. Distribution of invested ventures and invested amount by industry and country.

\begin{tabular}{|c|c|c|c|c|}
\hline Industry & $N$ obs & $\%$ & Invest. amount & $\%$ \\
\hline Food & I & 4.76 & 100,000 & 1.92 \\
\hline Manufacture of computer and electronics (ICT) & 2 & 9.52 & 710,000 & 13.67 \\
\hline Medical devices manufacturing & 5 & 23.81 & $2,110,000$ & 36.59 \\
\hline Energy & 3 & 14.29 & 850,000 & 16.36 \\
\hline Telecommunications (TLC) & 2 & 9.52 & 572,000 & 9.92 \\
\hline Computer programming and consultancy (Software) & I & 4.76 & 175,000 & 3.04 \\
\hline Information service (Internet) & 5 & 23.81 & 775,000 & 14.92 \\
\hline Biotechnology & 2 & 9.52 & 475,000 & 9.14 \\
\hline Total & 21 & 100 & $5,767,000$ & 100 \\
\hline \multicolumn{5}{|l|}{ Country } \\
\hline Italy & 15 & 71.43 & $4,135,000$ & 71.70 \\
\hline UK & 2 & 9.52 & 600,000 & 10.40 \\
\hline USA & 2 & 9.52 & 497,000 & 8.62 \\
\hline France & I & 4.76 & 210,000 & 3.64 \\
\hline Israel & I & 4.76 & 325,000 & 5.64 \\
\hline Total & 21 & 100 & $5,767,000$ & 100 \\
\hline
\end{tabular}

ICT: Information and Communication Technologies.

with business and law degrees favour Energy (29\% and 16\%, respectively) but invest less in the Internet sector ( $25 \%$ and $11 \%$, respectively). These descriptive statistics indicate that BAs rely more on industry experience, rather than educational attainment, when making investment choices.

\section{Background literature and hypotheses development}

An extensive literature on BA decision-making has identified a broad spectrum of factors that BAs consider when making a funding decision (see Maxwell et al., 2011, for a comprehensive list of investment decision criteria). These factors include easily verifiable firm-level financial information (e.g. sales) (Feeney et al., 1999), the target market (Clark, 2008; Feeney et al., 1999; Mason and Harrison, 1996; Mason and Rogers, 1997; Mason and Stark, 2004), the innovativeness of the product and its level of patent protection (Mason and Harrison, 1999; Mason and Stark, 2004), the business model (Wallnöfer and Hacklin, 2013) and the skills and experience of the entrepreneur/ management (Feeney et al., 1999; Haines et al., 2003; Mason and Stark, 2004; Smith et al., 2010; Van Osnabrugge, 2000). Scholars have noted that BAs largely base their decisions on subjective judgements and have a tendency to assign a substantial weight to the entrepreneur's characteristics when assessing a deal (Mason and Stark, 2004; Van Osnabrugge, 2000). Feeney et al. (1999) and Haines et al. (2003) list numerous personality factors related to the entrepreneurs considered by BAs, such as their commitment, openness, realism, integrity and work ethic. Clark (2008) extends this stream of research to impression management, finding that poor presentational skills during pitches strongly influence perceptions of potential for an investment opportunity.

Most research listing the criteria considered by BAs when selecting projects and allocating investments, analyses those BAs acting as individual investors rather than explicitly refer to specific stages of the investment process; equally, the focus is upon decisions during just a single phase of the decision-making process, using ex-post questionnaires, real-time methods and verbal protocols (Clark, 2008; Mason and Harrison, 2003; Mason and Rogers, 1997; Mason and Stark, 2004; Maxwell et al., 2011; Mitteness et al., 2012a, 2012b; Smith et al., 2010). This stream of 


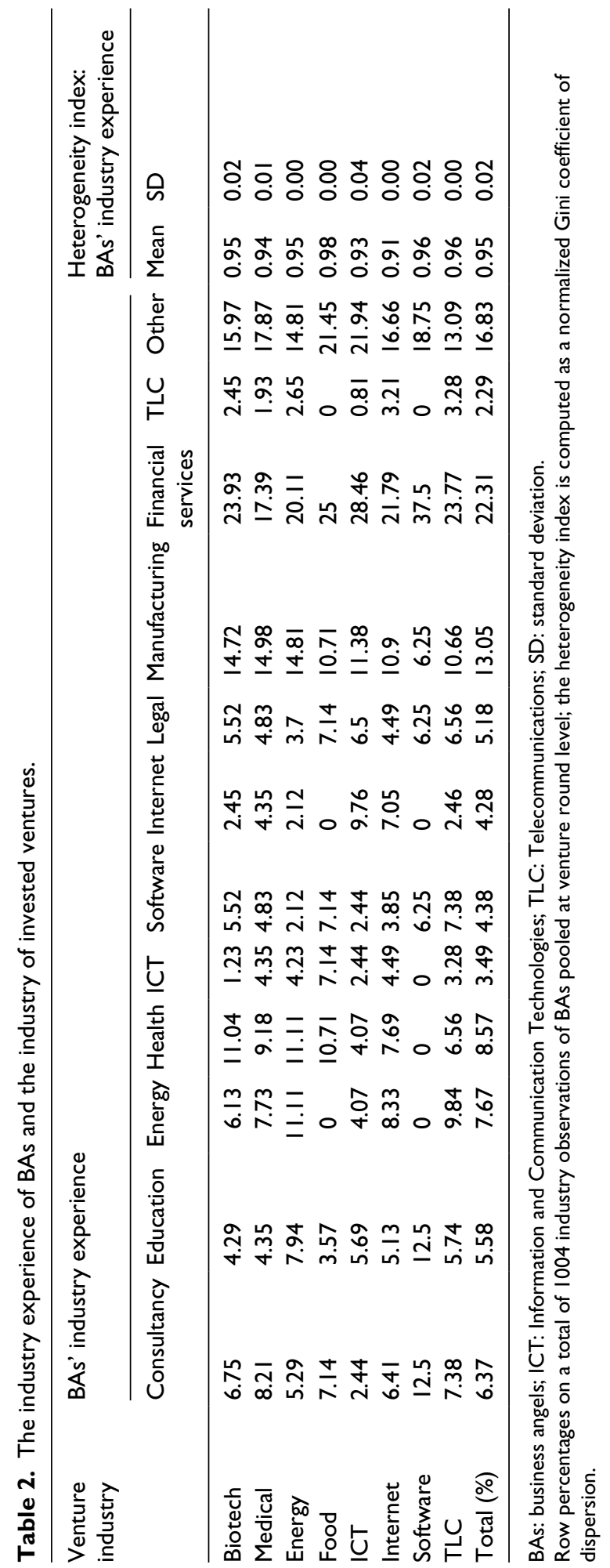




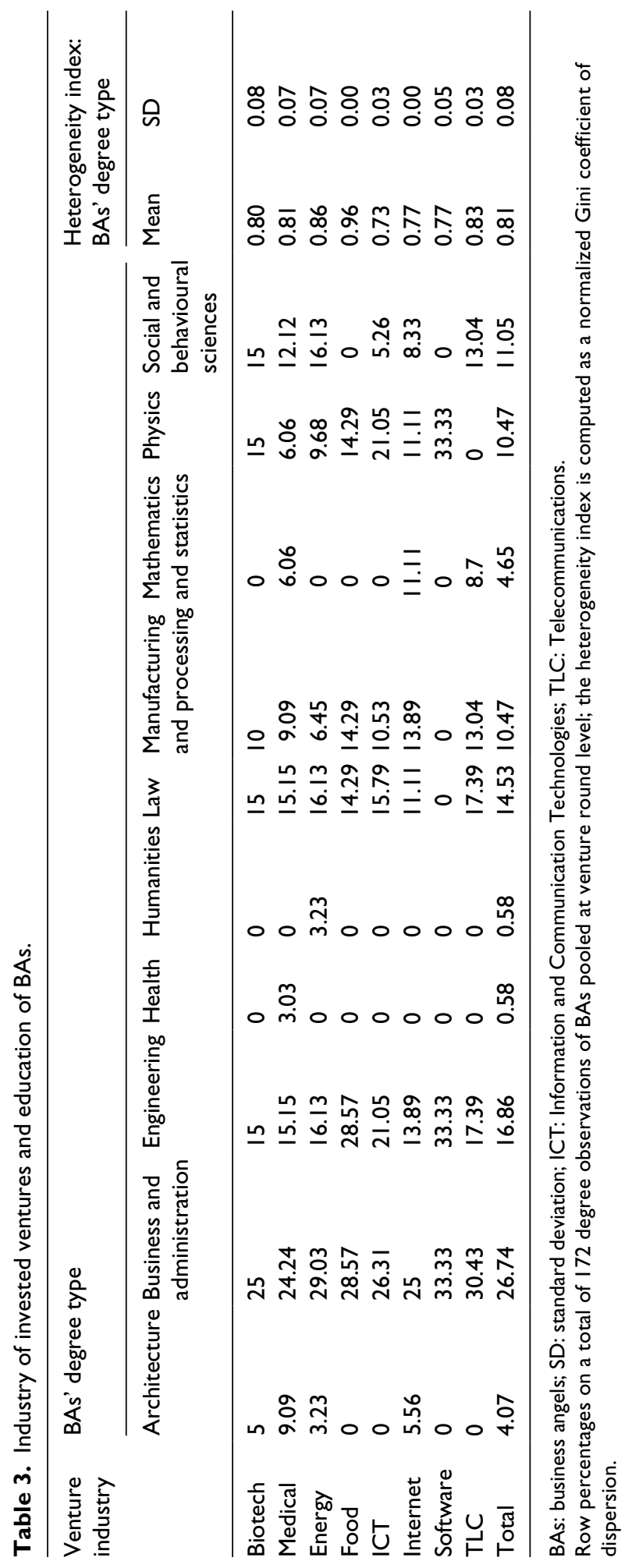


literature is based on independent investors, while limited evidence exists on angel groups (Mitteness et al., 2012a, 2012b).

Mitteness et al. (2012a) examined screening evaluations of BAs belonging to one of the largest angel investment group in the United States from 2007 to 2010. They report that the entrepreneur matters most when BAs are deciding whether a deal should proceed to due diligence. Maxwell et al. (2011) analyse a small set of interactions between entrepreneurs and BAs from a Canadian reality TV show; it was found that BAs reject a business opportunity due to a 'fatal flaw' (as perceived by the BA) during the initial stage of the investment decision process. The opportunities that progress beyond the initial stage are assessed more objectively based on market, technology, financial and entrepreneur-related criteria. Paul et al. (2007) gathered data from 30 interviews with BAs in Scotland and show that the key factor in determining whether the evaluation process goes any further is the impression that the BA has of the entrepreneur in the initial screening phases. As Mason and Harrison (2003) point out, the interaction between BAs and entrepreneurs is a multistage decision-making process in which BAs rely on different evaluation metrics as long as the selection procedure evolves. Attempts to study the multistage nature of BA decision-making with a specific focus on angel groups are still limited. Recently, the work by Brush et al. (2012) and Carpentier and Suret (2015) have explored the multistage nature of the BA decision-making process, from the initial project submission to the final decision, focusing on angel groups.

Brush et al. (2012) examined new venture investment readiness using a dataset of 332 firms seeking support from a prominent US angel group during 2007-2008. It was suggested that tangible, objective organizational characteristics were important during the first decision-making stage, while intangible, subjective new venture characteristics such as the trustworthiness, commitment, persuasiveness and passion of the top management team are more important during subsequent decision stages. Carpentier and Suret (2015) provide a detailed longitudinal analysis of the decision process of the members of a Canadian BA group noting that rejection reasons for proposals that pass the pre-screening mostly refer to market and execution risk while inexperienced entrepreneurs are rejected for market and product reasons.

In this article, we aim to explore whether rejection criteria adopted by a BA group vary during the different phases of the decision-making process. We assume that in the initial evaluation stage - pre-screening - the assessment, is based mainly on the general impression of the investment proposal and considerations regarding the commercialization potential of the product and its innovativeness (Landström, 1998; Mitteness et al., 2012a). As Brush et al. (2012) argue, BAs have to rule out the 'no hopers' in order to focus time and efforts on proposals that have potential. The low attractiveness of the product to potential customers in the target segment and its limited innovativeness are reported to be 'deal killers' (Mason and Harrison, 1996; Nofsinger and Wang, 2011). In particular, the existence of intellectual property protection and of a durable and reliable technology is often considered an important feature to move past the desk rejection stage (Brush et al., 2012). The decision whether to proceed to consider a detailed proposal depends largely on the quality of the business plan (Carpentier and Suret, 2015; Mason and Stark, 2004). Mason and Rogers (1997) find that poorly written business plans often result in proposal rejection. Instead, and compared to VCs, BAs seem to attach less importance in the initial screening stages to the market potential (Fiet, 1995), namely, to the assessment of the prospects and uncertainties of the firm's market such as size, accessibility, competitiveness and growth trends. According to Mason and Stark (2004), information on the market potential is rarely available due to limited resources to collect and analyse market-related information and to the lack of comparative data to assess market risk due to their small deal flows. We therefore expect the following:

HIa. In the pre-screening stage, BAs are more likely to reject business proposals without any apparent innovativeness. 
$H 1 b$. In the pre-screening stage, BAs are more likely to reject business proposals showing low growth potential.

During the subsequent evaluation screening phase, BAs evaluate the project proposals in more detail when considering them as an investment opportunity. With respect to VCs, BAs are more concerned with agency risk, caused by potentially divergent interests between entrepreneurs and investors that might prompt entrepreneurs not to act in the best interests of the investor (Collewaert and Sapienza, 2014; Sørheim, 2003). While formal institutional investors protect themselves against potential risks related to the entrepreneurial endeavour with the adoption of stringent contractual clauses, risk-sharing solutions and the staging of capital and active monitoring (Nofsinger and Wang, 2011), BAs usually apply simple and informal contracts with entrepreneurs and are not endowed with sophisticated monitoring mechanisms. Hence, in this phase they place greater emphasis on the judgement of the entrepreneur and the management team as a means to reduce agency risk (Maxwell and Lévesque, 2014). In particular, BAs judge the entrepreneur's attitude towards risk taking and commitment, trustworthiness, competences and managerial capabilities (Brush et al., 2012; Haines et al., 2003; Haynie et al., 2009; Parhankangas and Ehrlich, 2014). At this point, BAs also carefully assess whether the deal matches their personal investment goals and expectations (Haines et al., 2003; Mason and Stark, 2004; Mitteness et al., 2012a). In line with these predictions, we formulate the following hypothesis:

$H 2$. In the screening stage, BAs are more likely to reject business proposals by weak entrepreneurs/management teams.

In the final due diligence stage, BAs proceed to a thorough assessment of the project and a detailed analysis of the venture's financial situation is undertaken to determine whether the business model suggests a viable and profitable business. At this point, discussions are undertaken with the entrepreneur to inform the final decision on whether or not to fund the venture. Although the due diligence among BAs is not as formal and sophisticated as that conducted by VCs (Wiltbank, 2005), it covers an assessment of the firm growth perspectives and financial status. BAs are not as return-driven as VCs (Mason and Stark, 2004), and the importance that they attach to financial returns is frequently counterbalanced by considerations including the personal satisfaction that derives from playing a role in an entrepreneurial firm (Harrison and Mason, 2002; Van Osnabrugge and Robinson, 2000; Wetzel, 1983). BAs are in essence 'hands-on' investors, contributing their knowledge to the strategic and operational development of the investee businesses, by acting as board members or consultants (Colombo et al., 2014; Fiet, 1995; Harrison et al., 2010; Mason and Harrison, 1996; Paul et al., 2007). However, BAs use their own funds and are exposed to the risks and rewards of the investment. Therefore, financial considerations appear to play a dominant role in the evaluation of the proposal at this stage (Landström, 1998), although the factual evidence concerning the new venture and its quality could be scarce or absent (Parhankangas and Ehrlich, 2014). In line with these considerations, we expect the following:

H3. In the due diligence stage, BAs are more likely to reject business proposals by firms with poor financial records.

In the initial selection phases, BAs aim at selecting business proposals as efficiently as possible to focus their time and effort on the most valuable options (Madill et al., 2005). The majority of business proposals are rejected at the preliminary stages (Feeney et al., 1999; Landström, 1998; Mason and Harrison, 2003; Maxwell et al., 2011; Riding et al., 2007). Maxwell et al. (2011) indicate that BAs use a shortcut decision-making heuristic enabling them to reduce the large amount 
of available opportunities into a limited set of manageable proposals. After the initial phase, decision heuristics are abandoned in favour of a more complete set of screening criteria. The initial referral channel acts as an important filter to trim opportunities relatively quickly in the initial pre-screening phase. Mason and Rogers (1997) note that if the referral comes from a trusted and credible source, angels start their screening with a favourable attitude; conversely, if the source is unknown, angels are likely to adopt a more critical approach. The source from which a proposal is received sends a strong signal about the feasibility of the business opportunity for which investment is sought (Paul and Whittam, 2010). BA groups derive their information on investment opportunities from informal networks of friends and business associates, banks and VCs or other third parties (Harrison et al., 1997, 2010; Wetzel, 1983). Because of the information asymmetries that exist between start-ups and investors, it is critical for BAs to rely on third parties that can somehow certify the project value credibility. The informal intermediation of a third party is expected to be most effective in identifying investment proposals of interest that are likely to progress in the different evaluation phases, compared with business proposals that have not been recommended by any third party (for instance, those presented through the website). The reputation of a third party who brings the proposal to the attention of the angel group is found to have a positive effect on BA decisions (Baum and Silverman, 2004; Harrison et al., 1997; Landström, 1998). In particular, VC investors are usually regarded as a qualified source of information that can reduce information asymmetries related to the quality of the proposal and to the entrepreneur's reliability (Bian, 1997). We therefore expect the following:

H4. Business proposals that are recommended by a VC are more likely to move past the prescreening rejection stage.

\section{Data and methods}

\section{Dataset}

Our dataset includes 2161 ventures that sought angel investment from the members of IAG from February 2008 to April 2014. IAG provided access to their database under the explicit request that the information on all ventures and angels remain confidential. The dataset includes information on the localization and industry of the ventures applying for BA funding and on the motivations underlying the rejection of business proposals at the different phases of the investment process, as well as on the channels through which the projects have been forwarded to the BA group. Moreover, the sample also includes the successful deals and the corresponding list of BAs that made the investments. We matched such data with venture financial accounting records, retrieved from the AIDA (for Italian-based companies) and ORBIS (for foreign-based companies) commercial databases managed by Bureau Van Dijk. We also collected information regarding the educational and professional background of the members of IAG from Linkedin and/or other available web sources (e.g. AngelList, Crunchbase). We restricted the analysis only to those ventures (1942) which completed the evaluation process by April 2014, thus excluding on-going and suspended deals. Of these ventures, 21 were invested $(1.1 \%)$ by $118 \mathrm{BAs}$, for a total of 29 rounds of financing. ${ }^{5}$

\section{Variables}

A listing of the variables used in the empirical analysis along with their definitions is provided in Table 4 . The dependent variable is a categorical variable (rejected) that indicates in which phase of the investment process a business proposal has been rejected. It is equal to 0 if the venture was 
Table 4. Definition of the variables employed in the empirical analysis.

\begin{tabular}{|c|c|}
\hline Variable & Description \\
\hline Rejected & $\begin{array}{l}\text { Categorical variable equal to } 0 \text { if the venture was rejected after } \\
\text { the pre-screening stage (rejected after pre-screening), } I \text { if it was } \\
\text { rejected after the screening stage (rejected after screening) and } 2 \text { if } \\
\text { it was rejected after the due diligence (rejected after due diligence) }\end{array}$ \\
\hline \multicolumn{2}{|l|}{ Motivations for rejection } \\
\hline Low growth potential & $\begin{array}{l}\text { Dummy variable equal to } I \text { if the business proposal was rejected } \\
\text { because of a poor business potential and } 0 \text { otherwise }\end{array}$ \\
\hline $\begin{array}{l}\text { Weak entrepreneur/ } \\
\text { management team }\end{array}$ & $\begin{array}{l}\text { Dummy variable equal to } I \text { if the business proposal was rejected } \\
\text { because of a weak entrepreneur/management team and } 0 \\
\text { otherwise }\end{array}$ \\
\hline No innovativeness & $\begin{array}{l}\text { Dummy variable equal to I if the business proposal was rejected } \\
\text { because of a lack of apparent innovativeness and } 0 \text { otherwise }\end{array}$ \\
\hline Poor market potential & $\begin{array}{l}\text { Dummy variable equal to } I \text { if the business proposal was rejected } \\
\text { because of a poor market potential and } 0 \text { otherwise }\end{array}$ \\
\hline Poor investor-opportunity fit & $\begin{array}{l}\text { Dummy variable equal to } I \text { if the business proposal was rejected } \\
\text { because of a poor investor-opportunity fit and } 0 \text { otherwise }\end{array}$ \\
\hline \multicolumn{2}{|l|}{ Contact channel } \\
\hline BAN & $\begin{array}{l}\text { Dummy variable equal to } I \text { if the business proposal was forwarded } \\
\text { by a BAN and } 0 \text { otherwise }\end{array}$ \\
\hline IAG & $\begin{array}{l}\text { Dummy variable equal to } I \text { if the business proposal was forwarded } \\
\text { by a member of IAG and } 0 \text { otherwise }\end{array}$ \\
\hline VC & $\begin{array}{l}\text { Dummy variable equal to } I \text { if the business proposal was forwarded } \\
\text { by a VC and } 0 \text { otherwise }\end{array}$ \\
\hline Event & $\begin{array}{l}\text { Dummy variable equal to } I \text { if the business proposal was presented } \\
\text { in a formal event (meeting/conference) and } 0 \text { otherwise }\end{array}$ \\
\hline Incubator & $\begin{array}{l}\text { Dummy variable equal to } I \text { if the business proposal was forwarded } \\
\text { by an incubator and } 0 \text { otherwise }\end{array}$ \\
\hline Website & $\begin{array}{l}\text { Dummy variable equal to } I \text { if the business proposal was forwarded } \\
\text { through the IAG website and } 0 \text { otherwise }\end{array}$ \\
\hline \multicolumn{2}{|c|}{ Financial indicators and firm-level variables } \\
\hline IntangiblesK & Intangible assets/total assets \\
\hline ROE & Net profit/equity \\
\hline Current ratio & Current assets/current liabilities \\
\hline DebtK & Long term liabilities/total assets \\
\hline LogK & Logarithm of total assets \\
\hline Distance & Logarithm of geographical distance in miles \\
\hline Age & Logarithm of firm age in the year of the evaluation \\
\hline
\end{tabular}

BAN: business angel network; IAG: Italian Angels for Growth; ROE: return on equity; VC: venture capital.

rejected after the pre-screening stage (rejected after pre-screening), 1 if it was rejected after the screening stage (rejected after screening) and 2 if it was rejected after the due diligence (rejected after due diligence). The independent variables include the motivations underlying the rejection decisions, the channels through which the business proposals are forwarded to the BA group and indicators of firm financial status.

The original database provided a series of written comments regarding the reasons why a proposal under scrutiny was rejected in the pre-screening and screening phases. We have codified such 
Table 5. Distribution of the sample by year of evaluation.

\begin{tabular}{|c|c|c|c|c|c|c|c|c|c|c|}
\hline \multirow[t]{2}{*}{ Year } & \multicolumn{2}{|c|}{$\begin{array}{l}\text { Rejected after } \\
\text { pre-screening }\end{array}$} & \multicolumn{2}{|c|}{$\begin{array}{l}\text { Rejected after } \\
\text { screening }\end{array}$} & \multicolumn{2}{|c|}{$\begin{array}{l}\text { Rejected after } \\
\text { due diligence }\end{array}$} & \multicolumn{2}{|c|}{ Invested } & \multicolumn{2}{|l|}{ Total } \\
\hline & $N$ obs & $\%$ & $N$ obs & $\%$ & $N$ obs & $\%$ & $N$ obs & $\%$ & $N$ obs & $\%$ \\
\hline 2008 & 144 & 67.92 & 57 & 26.9 & 9 & 4.25 & 2 & 0.94 & 212 & 10.9 \\
\hline 2009 & 179 & 66.05 & 78 & 28.8 & 11 & 4.06 & 3 & 1.11 & $27 I$ & 14.0 \\
\hline 2010 & 273 & 73.39 & 84 & 22.6 & 10 & 2.69 & 5 & 1.34 & 372 & 19.2 \\
\hline 2011 & 318 & 76.08 & 89 & 21.3 & 7 & 1.67 & 4 & 0.96 & 418 & 21.5 \\
\hline 2012 & 240 & 73.39 & 75 & 22.9 & 11 & 3.36 & I & 0.31 & 327 & 16.8 \\
\hline 2013 & 181 & 68.30 & 75 & 28.3 & 3 & 1.13 & 6 & 2.26 & 265 & 13.6 \\
\hline 2014 & 46 & 82.14 & 8 & 14.3 & 2 & 3.57 & 0 & 0.00 & 56 & 2.9 \\
\hline Total & $138 \mid$ & 71.89 & 466 & 24.25 & 53 & 2.76 & 21 & 1.09 & 1921 & \\
\hline
\end{tabular}

comments into five major categories: low growth potential (e.g. in terms of completeness and soundness of the business plan and business growth prospects), weak entrepreneur/management team (e.g. lack of trustworthiness, competence, and commitment), no apparent innovativeness (e.g. little or no innovativeness and lack of proprietary technology), poor market potential (e.g. a market that is too localized, little and/or mature, the presence of high entry barriers and severe competition), and poor investor-opportunity fit (e.g. wrong investment target, lack of geographical closeness and of a reasonable exit plan).

Raw data also include interesting comments on the different channels through which business proposals have been forwarded to IAG. The proposals can be forwarded through the IAG website, presented in a formal event as a meeting/conference, advanced directly by a member of IAG or by a VC fund, an incubator or a BAN.

In addition to the qualitative information on the reasons for the rejection of business proposals and on the contact channels, we have gathered quantitative data on the financial status of the applicant's ventures in the years before evaluation. We have thus considered a set of financial and economic indicators, including size (measured by total assets, in logarithms), liquidity (current ratio), profitability (ROE), leverage (long term liabilities over total assets) and incidence of intangible assets (intangibles assets over total assets). Other control variables are the age of the venture at the time of the evaluation and the distance between the venture's headquarters and the BA group's main office.

\section{Descriptive statistics}

Table 5 reports the number of business proposals that have been rejected at each evaluation stage and the number of invested ventures across the years. Nearly $72 \%$ of the ventures did not get through the pre-screening phase, more than $24 \%$ were rejected after the screening stage and only about $3 \%$ were rejected after the due diligence. A total of 21 ventures $(1.1 \%)$ were finally invested. This rejection rate above $90 \%$ is consistent with other research (Mitteness et al., 2012a; Harrison et al., 1997). The table illustrates that the percentage incidence of the pre-screening rejections has a pick in 2011 (76\%), which coincides with the year in which the IAG group received the largest number of the applications. In general, the rate of rejection in the screening phase counterbalances the fluctuations that take place in the pre-screening stage. Instead, the percentage of ventures that did not get through the due diligence is steadier across the years (around 10 proposals per year), with the exception of 2013, when out of a greater percentage of ventures rejected after the screening $(28 \%)$, only $1 \%$ was rejected after due diligence. 
Table 6. Distribution of the sample by industry and country.

\begin{tabular}{|c|c|c|c|c|}
\hline Industry & $N$ obs & $\%$ & $\begin{array}{l}\text { NACE rev. } \\
2 \text { section }\end{array}$ & $\begin{array}{l}\text { NACE rev. } \\
2 \text { codes }\end{array}$ \\
\hline Food & 53 & 2.73 & $A$ & 01 \\
\hline Chemicals & 18 & 0.93 & C & 20 \\
\hline Pharmaceuticals & 21 & 1.08 & $\mathrm{C}$ & 21 \\
\hline $\begin{array}{l}\text { Manufacture of computer and } \\
\text { electronics }\end{array}$ & 86 & 4.43 & C & 26 \\
\hline $\begin{array}{l}\text { Manufacture of machinery and } \\
\text { equipment }\end{array}$ & 91 & 4.69 & C & 28 \\
\hline $\begin{array}{l}\text { Automotive (and other motor vehicles } \\
\text { manufacturing) }\end{array}$ & 53 & 2.73 & C & $29-30$ \\
\hline Medical devices manufacturing & 81 & 4.17 & C & 32 \\
\hline Other manufacturing & 55 & 2.83 & C & $10-30$ \\
\hline Energy (electricity, gas, steam supply) & 129 & 6.64 & $\mathrm{D}$ & 35 \\
\hline Retail/e-commerce & 90 & 4.63 & G & 47 \\
\hline Telecommunications & 244 & 12.56 & $J$ & 61 \\
\hline $\begin{array}{l}\text { Computer programming and } \\
\text { consultancy (Software) }\end{array}$ & 156 & 8.03 & j & 62 \\
\hline Information service (Internet) & 516 & 26.57 & J & 63 \\
\hline Financial and Insurance services & 59 & 3.04 & $\mathrm{~K}$ & $64-66$ \\
\hline $\begin{array}{l}\text { Professional, scientific and technical } \\
\text { activities }\end{array}$ & 64 & 6.18 & M & $69-74$ \\
\hline Biotechnology & 51 & 2.63 & M & 72 \\
\hline Art and Entertainment & 42 & 2.16 & $\mathrm{R}$ & $90-93$ \\
\hline Other & 133 & 6.85 & & \\
\hline Total & 1942 & 100 & & \\
\hline Country & $N$ obs & $\%$ & & \\
\hline Italy & 1035 & 76.16 & & \\
\hline UK & 75 & 5.52 & & \\
\hline USA & 63 & 4.64 & & \\
\hline Switzerland & 42 & 3.09 & & \\
\hline Germany & 16 & 1.18 & & \\
\hline Israel & 15 & 1.10 & & \\
\hline France & 13 & 0.96 & & \\
\hline Spain & 11 & 0.81 & & \\
\hline Canada & 9 & 0.66 & & \\
\hline Sweden & 5 & 0.37 & & \\
\hline Other EU & 34 & 2.5 & & \\
\hline Other America & 8 & 0.59 & & \\
\hline Other & 33 & 2.43 & & \\
\hline Total & 1359 & 100.00 & & \\
\hline
\end{tabular}

NACE: Nomenclature des Activités Économiques dans la Communauté Européenne; EU: European Union.

Table 6 illustrates the distribution of the sample by industry and country. We classify the ventures into industries on the basis of the NACE (Nomenclature des Activités Économiques dans la Communauté Européenne) rev. 2 industry codes; they belong mostly to the ICT sectors. Internet is the leading industry $(26.6 \%)$, followed by Telecommunications $(12.6 \%)$ and Software (8\%). 
Table 7. Descriptive statistics on the financial status of the ventures that have been rejected in the prescreening, screening and due diligence stages.

\begin{tabular}{|c|c|c|c|c|c|c|c|c|}
\hline & \multicolumn{2}{|c|}{$\begin{array}{l}\text { Rejected after pre- } \\
\text { screening }\end{array}$} & \multicolumn{2}{|c|}{$\begin{array}{l}\text { Rejected after } \\
\text { screening }\end{array}$} & \multirow{2}{*}{$\begin{array}{l}\text { Difference } \\
(2)-(I)\end{array}$} & \multicolumn{2}{|c|}{$\begin{array}{l}\text { Rejected after } \\
\text { due diligence }\end{array}$} & \multirow{2}{*}{$\begin{array}{l}\text { Difference } \\
(3)-(1)\end{array}$} \\
\hline & $N$ obs & Mean (I) & Nobs & Mean (2) & & Nobs & Mean (3) & \\
\hline IntangiblesK & 1249 & 0.204 & 589 & 0.2855 & $0.0815^{* * *}$ & 103 & 0.333 & $0.129 * * *$ \\
\hline ROE & 1203 & -0.131 & 549 & -0.198 & -0.067 & 100 & -0.447 & $-0.316^{*}$ \\
\hline Current ratio & 1145 & 2.290 & 490 & 2.654 & $0.364^{*}$ & 81 & 2.330 & 0.040 \\
\hline DebtK & 1152 & 0.116 & 496 & 0.115 & -0.001 & 82 & 0.115 & -0.001 \\
\hline LogK & 1278 & 5.531 & 613 & 5.256 & $-0.275^{* *}$ & 106 & 5.810 & $0.279 *$ \\
\hline Distance & 832 & 3808.187 & 419 & 3778.667 & -29.521 & 50 & 3183.70 & -624.483 \\
\hline Age (years) & 334 & 5.506 & 183 & 3.759 & $-1.746 * * *$ & 26 & 4.615 & -0.89 |** \\
\hline
\end{tabular}

ROE: return on equity.

Mean values for the years prior to the evaluation, including the evaluation year.

Significance at $* * * 1 \%, * * 5 \%$ and $* 10 \%$ levels.

The second most represented sector is Manufacturing, with nearly $8 \%$ of the ventures belonging to the medical devices (4.4\%), pharmaceuticals (1\%) and biotechnology $(2.6 \%)$ industries. Regarding the geographical distribution of the ventures, the largest majority $(76 \%)$ are located in Italy, followed by other European countries (15\%) and the United States (5\%). In particular, the United Kingdom accounts for 77 applicant ventures, followed by Switzerland (42), Germany (16) and France (14).

Table 7 provides descriptive statistics on the financial status of the ventures that have been rejected in the pre-screening, screening and due diligence stages. Financial indicators are calculated as a mean over the years before the evaluation date, including the year of the evaluation. Ventures that have been rejected in the screening and due diligence phases are on average younger and show higher intangible ratios in comparison with those that have been rejected in the prescreening stage. This seems to be in line with BA overall preferences to invest in ventures in the early stages of development and their tendency to screen out ventures showing poor growth opportunities in the first phases of the investment decision process. Moreover, ventures that have been rejected in the screening stage are, on average, smaller (lower total assets) and show higher levels of liquidity (higher current ratio) than those rejected in the pre-screening phase. Ventures rejected after due diligence are bigger and, not surprisingly, less profitable (lower ROE) than the other two categories, although it has to be remarked that all the considered ventures show, on average, a negative profitability. Finally, leverage is similar across the different groups of firms and is quite low $(12 \%)$.

Table 8 reports the percentage incidence of the criteria that drive rejection decisions in the prescreening and screening phases. As each business proposal may be rejected for more than one reason, in no specific order of importance, we pooled together all the motivations for each venture. Most business proposals were rejected because of their low growth potential or poor investoropportunity fit in both the pre-screening and screening stages, accounting for a total of nearly $60 \%$ and $70 \%$ of rejections, respectively. ${ }^{6}$ However, it also emerges that the lack of innovativeness is significantly higher for business proposals rejected after the pre-screening in comparison with those rejected after the screening stage ( $28 \%$ vs $10 \%$, respectively). The opposite holds true when examining the motivation concerning a weak entrepreneur/management team leading to a rate of rejection of $6 \%$ in the pre-screening stage and $13 \%$ in the screening stage. 
Table 8. Motivations driving the rejection of business proposals in the pre-screening and screening stages.

\begin{tabular}{lllllll}
\hline & $\begin{array}{l}\text { Low growth } \\
\text { potential }\end{array}$ & $\begin{array}{l}\text { Weak } \\
\text { entrepreneur/ } \\
\text { management } \\
\text { team }\end{array}$ & $\begin{array}{l}\text { No } \\
\text { innovativeness }\end{array}$ & $\begin{array}{l}\text { Poor } \\
\text { market } \\
\text { potential }\end{array}$ & $\begin{array}{l}\text { Poor investor- Total } \\
\text { opportunity fit }\end{array}$ & \\
\hline $\begin{array}{l}\text { Rejected after } \\
\text { pre-screening }\end{array}$ & $551(30.39 \%)$ & $105(5.79 \%)$ & $501(27.63 \%)$ & $134(7.39 \%)$ & $522(28.79 \%)$ & $1813(100 \%)$ \\
$\begin{array}{l}\text { Rejected after } \\
\text { screening }\end{array}$ & $173(32.89 \%)$ & $68(12.93 \%)$ & $51(9.70 \%)$ & $46(8.75 \%)$ & $188(35.74 \%)$ & $526(100 \%)$ \\
$\begin{array}{l}\text { Total } \\
724(30.95 \%)\end{array}$ & $\begin{array}{l}173(7.40 \%) \\
\text { Pearson } \chi^{2}(4)=91.9415 ; P r=0.000\end{array}$ & $552(23.60 \%)$ & $180(7.70 \%)$ & $710(30.35 \%)$ & $2339(100 \%)$ \\
\hline
\end{tabular}

Table 9. Contact channels through which business proposals have been forwarded to IAG in the different evaluation stages.

\begin{tabular}{llllllll}
\hline & BAN & IAG & VC & Event & Incubator & Website & Total \\
\hline $\begin{array}{l}\text { Rejected after } \\
\text { pre-screening }\end{array}$ & $160(10.62 \%)$ & $530(35.19 \%)$ & $40(2.66 \%)$ & $137(9.1 \%)$ & $35(2.32 \%)$ & $604(40.11 \%)$ & $1506(100 \%)$ \\
$\begin{array}{l}\text { Rejected after } \\
\text { screening }\end{array}$ & $57(10.67 \%)$ & $248(46.44 \%)$ & $34(6.37 \%)$ & $120(22.47 \%)$ & $26(4.87 \%)$ & $49(9.18 \%)$ & $534(100 \%)$ \\
$\begin{array}{l}\text { Rejected after } \\
\text { due diligence }\end{array}$ & $10(14.49 \%)$ & $28(40.58 \%)$ & $13(18.84 \%)$ & $11(15.94 \%)$ & $6(8.7 \%)$ & $1(1.45 \%)$ & $69(100 \%)$ \\
$\begin{array}{l}\text { Total } \\
\text { Pearson chi2(10)=277.3655; Pr=0.000 }\end{array}$ & $\begin{array}{l}227(10.76 \%) \\
806(38.22 \%)\end{array}$ & $87(4.13 \%)$ & $268(12.71 \%)$ & $67(3.18 \%)$ & $654(31.01 \%)$ & $2109(100 \%)$ \\
\hline
\end{tabular}

IAG: Italian Angels for Growth; BAN: business angel network; VC: venture capital.

Finally, Table 9 provides descriptive statistics on the contact channels through which the business proposals are forwarded to IAG. As each proposal can come through different channels, we pooled them together at venture level to compute the statistics. It emerges that the website is the most common channel to approach the BA group by ventures that are rejected after the pre-screening phase $(40 \%$ vs an average of $31 \%$ for the ventures that came into contact with the group through this channel). Instead, a business proposal that is put forward by either IAG members or through face-to-face events is more likely to reach the screening stage ( $46 \%$ and $23 \%$, respectively). Also, the VC and BAN channels seem to be the most important ones to proceed to due diligence in the later stages of the evaluation process.

\section{Econometric results}

Table 10 shows the estimation results. To test the research hypotheses $\mathrm{H} 3$ and H4, we first resort to a sequential logit model (columns I and II). The dependent variable is the categorical variable 'rejected', indicating the stage of the decision-making process in which a venture's business proposal was rejected. The base outcome is 'rejected after pre-screening'. In columns I and II, we show the average marginal effects related to the transition probability, that is, the probability that a proposal moves from the pre-screening to the screening stage (I) and from the screening to the due diligence stage (II). Independent variables include the financial records of the ventures in the years before the evaluation including intangible assets, measures of profitability (ROE), liquidity 
Table 10. Sequential logit and probit models: marginal effects.

\begin{tabular}{|c|c|c|c|c|c|}
\hline & \multicolumn{2}{|c|}{ Seqlogit: transition probabilities } & \multicolumn{2}{|c|}{ Probit (control function) } & \multirow{2}{*}{$\begin{array}{l}\text { Probit } \\
\text { Rejected after } \\
\text { screening }\end{array}$} \\
\hline & $\begin{array}{l}\text { Rejected after } \\
\text { screening }\end{array}$ & $\begin{array}{l}\text { Rejected after } \\
\text { due diligence }\end{array}$ & $\begin{array}{l}\text { Rejected after } \\
\text { screening }\end{array}$ & $\begin{array}{l}\text { Rejected after } \\
\text { due diligence }\end{array}$ & \\
\hline & I & II & III & IV & V \\
\hline IntangiblesK & $\begin{array}{l}0.2666 * * * \\
(0.0896)\end{array}$ & $\begin{array}{l}-0.0921 \\
(0.1212)\end{array}$ & $\begin{array}{l}0.5290 * * \\
(0.2479)\end{array}$ & $\begin{array}{l}0.0366 \\
(0.0399)\end{array}$ & $\begin{array}{l}0.2746 * * * * \\
(0.0876)\end{array}$ \\
\hline ROE & $\begin{array}{l}-0.0178 \\
(0.0260)\end{array}$ & $\begin{array}{l}-0.077 \mid * * * * \\
(0.0243)\end{array}$ & $\begin{array}{l}-0.0463 \\
(0.0374)\end{array}$ & $\begin{array}{l}-0.0265^{* * *} \\
(0.0102)\end{array}$ & $\begin{array}{l}-0.0140 \\
(0.0261)\end{array}$ \\
\hline Current ratio & $\begin{array}{l}0.0123^{*} \\
(0.0071)\end{array}$ & $\begin{array}{l}0.0001 \\
(0.007)\end{array}$ & $\begin{array}{l}0.0301 * * \\
(0.0147)\end{array}$ & $\begin{array}{l}0.0019 \\
(0.0029)\end{array}$ & $\begin{array}{l}0.0180 * * * * \\
(0.0061)\end{array}$ \\
\hline DebtK & $\begin{array}{l}0.0269 \\
(0.1241)\end{array}$ & $\begin{array}{l}0.0712 \\
(0.1273)\end{array}$ & $\begin{array}{l}0.0793 \\
(0.1113)\end{array}$ & $\begin{array}{l}-0.0315 \\
(0.0537)\end{array}$ & $\begin{array}{l}-0.0890 \\
(0.1107)\end{array}$ \\
\hline LogK & $\begin{array}{l}0.0024 \\
(0.0168)\end{array}$ & $\begin{array}{l}0.0148 \\
(0.0242)\end{array}$ & $\begin{array}{l}0.0250 \\
(0.0189)\end{array}$ & $\begin{array}{l}-0.0010 \\
(0.0065)\end{array}$ & $\begin{array}{l}0.0229 \\
(0.0160)\end{array}$ \\
\hline Distance & $\begin{array}{l}-0.0079 \\
(0.0104)\end{array}$ & $\begin{array}{l}-0.0054 \\
(0.0119)\end{array}$ & $\begin{array}{l}-0.0082 \\
(0.0117)\end{array}$ & $\begin{array}{l}-0.0058 \\
(0.0038)\end{array}$ & $\begin{array}{l}0.0064 \\
(0.0103)\end{array}$ \\
\hline Age & $\begin{array}{l}-0.0138 \\
(0.0410)\end{array}$ & $\begin{array}{l}0.0965 * * * \\
(0.0371)\end{array}$ & $\begin{array}{l}-0.0730 * \\
(0.0405)\end{array}$ & $\begin{array}{l}0.0373^{* *} \\
(0.0165)\end{array}$ & $\begin{array}{l}-0.0070 \\
(0.0393)\end{array}$ \\
\hline $\begin{array}{l}\text { Inverse Mills } \\
\text { Ratio_I }\end{array}$ & & & $\begin{array}{l}2.0504 \\
(1.6089)\end{array}$ & & \\
\hline $\begin{array}{l}\text { Inverse Mills } \\
\text { Ratio_2 }\end{array}$ & & & & $\begin{array}{l}0.1214 \\
(0.1635)\end{array}$ & \\
\hline BAN & $\begin{array}{l}0.3210 * * * \\
(0.0881)\end{array}$ & & $\begin{array}{l}0.4856 * * * \\
(0.1115)\end{array}$ & & $\begin{array}{l}0.2933^{* * * *} \\
(0.0840)\end{array}$ \\
\hline IAG & $\begin{array}{l}0.2694 * * * \\
(0.0500)\end{array}$ & & $\begin{array}{l}0.3244 * * * \\
(0.0513)\end{array}$ & & $\begin{array}{l}0.1910 * * * * \\
(0.0480)\end{array}$ \\
\hline VC & $\begin{array}{l}0.4726 * * * \\
(0.1051)\end{array}$ & & $\begin{array}{l}0.6432 * * * \\
(0.1847)\end{array}$ & & $\begin{array}{l}0.4109 * * * * \\
(0.1056)\end{array}$ \\
\hline Event & $\begin{array}{l}0.3220 * * * \\
(0.0687)\end{array}$ & & $\begin{array}{l}0.4090 * * * \\
(0.0887)\end{array}$ & & $\begin{array}{l}0.2024^{* * * *} \\
(0.0652)\end{array}$ \\
\hline Incubator & $\begin{array}{l}0.198 I^{*} \\
(0.1191)\end{array}$ & & $\begin{array}{l}0.1288^{*} \\
(0.0701)\end{array}$ & & $\begin{array}{l}0.3296 * * \\
(0.1462)\end{array}$ \\
\hline $\begin{array}{l}\text { Low growth } \\
\text { potential }\end{array}$ & & & & & $\begin{array}{l}0.0291 \\
(0.0533)\end{array}$ \\
\hline $\begin{array}{l}\text { Weak } \\
\text { entrepreneur/ } \\
\text { management } \\
\text { team }\end{array}$ & & & & & $\begin{array}{l}0.202 I^{* *} \\
(0.0923)\end{array}$ \\
\hline $\begin{array}{l}\text { No } \\
\text { innovativeness }\end{array}$ & & & & & $\begin{array}{l}-0.1298^{* * *} \\
(0.0554)\end{array}$ \\
\hline $\begin{array}{l}\text { Poor market } \\
\text { potential }\end{array}$ & & & & & $\begin{array}{l}-0.0943 \\
(0.0780)\end{array}$ \\
\hline $\begin{array}{l}\text { Industry } \\
\text { dummies }\end{array}$ & Yes & Yes & Yes & Yes & Yes \\
\hline Year dummies & Yes & Yes & Yes & Yes & Yes \\
\hline $\begin{array}{l}\text { Number of } \\
\text { observations }\end{array}$ & 467 & 467 & 467 & 467 & 430 \\
\hline
\end{tabular}

ROE: return on equity; BAN: business angel network; IAG: Italian Angels for Growth; VC: venture capital.

The table reports the marginal effects for sequential logit models (columns I-II) and probit models (columns III-V).

Robust standard errors are reported in parentheses. The base outcome for the sequential logit is rejection after prescreening. The base category for the contact channels is the categorical variable 'Website'. The base category for the motivations for rejection is the categorical variable 'Poor investor-opportunity fit'.

Significance at $* * * 1 \%, * * 5 \%$ and $* 10 \%$ levels. 
(current ratio), debt level and size (logarithm of total assets) and the contact channels through which the business proposals have been forwarded to the BA group. It is worth noting that the variables on contact channels are introduced only in the model estimating the probability that a proposal moves from the pre-screening to the screening stage. Contact channels are instead not included in the due diligence phase as they should no longer influence BA decisions at this stage. In all models, we control for the age of the venture and for the geographical distance between the venture headquarters and IAG offices. Year and industry dummies are also included in all the estimates.

Results reported in column I show that proposals brought to the angel group's attention by BANs, IAG associates, VCs, incubators or presented during face to face events are more likely to be rejected after the screening stage with respect to pre-screening. Results show that business proposals advanced by VCs have $47.26 \%$ more chance to get through the pre-screening stage, as measured by the transition probability. Thus, we find support for $\mathrm{H} 4$. We interpret this result in the light of the certification role exerted by VCs on the quality of the ventures, which allows business proposals to proceed through the first phase of the investment process.

Concerning financial indicators, it emerges that a higher incidence of intangible assets increases the probability of rejection after the screening stage compared to the pre-screening stage as indicated by the coefficient of intangibles in column I that are positive and significant at $1 \%$ significance levels. Moreover, higher liquidity significantly (at 10\% significance level) increases the likelihood of a proposal to move from the pre-screening to the screening stage (column I). Hence, a higher incidence of intangible assets and liquidity increases the likelihood that a proposal will proceed through the first stage of selection and move to the screening stage. In accordance with $\mathrm{H} 3$, in the due diligence stage, BAs are more likely to reject business proposals by firms with poor financial records. In fact, ventures rejected after the due diligence show a lower profitability (ROE), as indicated in column II. However, we do not find any evidence that ventures with higher levels of debt or lower levels of liquidity are more likely to fail the due diligence evaluation. Finally, firm age increases the likelihood that a proposal gets through the screening phase and is rejected after the due diligence.

As a robustness check, in columns III and IV we resort to a 'control function approach' to take into account the issue of selection related to our model: actually, the analysed process clearly exhibits a sequential nature, as only ventures which are not rejected in the previous stage proceed up to the following stage of selection. In particular, we estimate the probability that a proposal is rejected in a subsequent stage by including, among the covariates, the inverse Mills' ratio estimated in the previous step. More in detail, column III shows the average marginal effects of the probit model estimating the likelihood that a proposal is rejected after the screening stage. In this model, we include the inverse Mills ratio generated from the model estimating the probability to be rejected in the pre-screening step. Column IV reports the average marginal effects of the probit model estimating the likelihood that a proposal is rejected after due diligence. In this model, we include the inverse Mills ratio generated from the model estimating the probability to be rejected after the screening stage. Results of these estimates provide a confirmation of previous results related to the contact channels, with an even stronger effect exerted by the VC channel, and the financial records of the ventures.

To test $\mathrm{H} 1$ and $\mathrm{H} 2$, we resort to a probit model on the restricted sample of ventures that have been rejected in the pre-screening and screening phases, for which data on the motivations of the rejection are available. The dependent variable is a dummy variable that takes the value of 1 if the venture was rejected in the screening stage and 0 otherwise. The independent variables include the motivations of the refusal (poor investor-opportunity fit is the base outcome), the contact channels (website is the base outcome) and the venture's financial records. The average marginal effects of 
the probit model are reported in column V of Table 7. Results suggest that the lack of apparent innovativeness of the business proposal significantly decreases by $12.91 \%$ the probability of being rejected at the screening phase, whereas a weak entrepreneur/management team significantly increases such probability by $20.21 \%$. Thus, we find support for the H1a and H2. Indeed, H1a is verified because the lack of innovativeness seems to be a more important motivation of refusal in the pre-screening phase than in the screening phase. We also find support for $\mathrm{H} 2$ since the characteristics of the entrepreneur and management team matter most in the screening phase, when an actual interaction between the entrepreneur and the BAs takes place. Instead, the growth potential of the business proposal does not play any role in either the pre- or post- screening phases and $\mathrm{H} 1 \mathrm{~b}$ is therefore not supported.

As additional evidence, we also estimated the predicted probability that an 'ideal' business proposal rejected at one particular stage is then rejected at the subsequent stage. Results of this analysis show that a proposal which is rejected in the pre-screening stage is also rejected in $90 \%$ of the cases after the screening stage, ${ }^{7}$ while a proposal that is rejected in the screening stage has a probability of $75 \%$ to be rejected after the due diligence. ${ }^{8}$

\section{Conclusion}

In this article, we have investigated how BAs evaluate new entrepreneurial ventures, by studying the criteria that drive rejections of investment proposals, as well as the contact channels through which projects are forwarded, across different assessment phases such as pre-screening, screening and due diligence. We have exploited an original dataset of 1942 ventures that sought angel investment from 2008 to 2014 from the members of IAG, a prominent Italian BA group.

The analysis shows that the emphasis BAs place on rejection criteria and contact channels varies along the three considered stages of the investment process. In particular, we found that business proposals brought to BA attention by VCs are more likely to get through the pre-screening stage, suggesting an important quality certification role played by VCs. Moreover, at the screening stage, in comparison with the pre-screening stage, proposals are rejected more often for reasons related to the characteristics of the entrepreneur and management team and less often for a lack of business innovativeness. Finally, business proposal showing lower levels of profitability are more likely to be rejected after due diligence.

The study has some limitations that suggest future avenues of research. First, the rejection decisions made along the analysed stages up to the due diligence stage are not taken by single BAs, but by IAG as a group. Therefore, we are not able to link BA individual characteristics, such as education or industry background, to rejection decisions. Future research should investigate to what extent investor characteristics influence preferences. Second, because of the confidential nature of the angel investment process, we have no access to information on business plans. Future research using data on evaluated business plans would enhance our understanding of the angel investment process. Finally, we relied on data from only one angel investment group, located in Northern Italy. We hope that this study will spur future research in further enhancing the understanding of the BA investment process with larger datasets and in new settings.

Our work suggests implications for both entrepreneurs seeking funding and for BAs evaluating business proposals. From the entrepreneur's point of view, evidence that desk rejections typically concern projects that do not match the scope of action of the angel group suggests that applicants should take time in understanding the angel group's objectives and targets. Moreover, since in the pre-screening phase the IAG staff is mainly in charge of assessing the quality of the proposals, entrepreneurs that want to move past the pre-screening stage have to make an effort when detailing, documenting and structuring the submitted projects. This may involve providing descriptions of market penetration and exit strategies, the innovativeness and scalability of the products, the target customers 
and so on. The importance that the angel group attaches to the innovativeness of the proposal and quality of the entrepreneur/management team as discriminating factors to move past the screening stages also suggests that entrepreneurs need to be technologically and organizationally competent. Solid financial records are important if the venture aims at proceeding to the due diligence stage. In sum, a better understanding of the most common causes for rejection in the different evaluation stages can help entrepreneurs seeking BA financing to market themselves and their business proposals more effectively and to increase final success rate. From the BA's perspective, being organized into a managed group clearly challenges the traditional approach typical of solo angels. The final selection of the investments is driven in by the rejection criteria adopted by the group and by group thinking dynamics. However, individual angels can benefit from a greater professionalism and a better screening of the proposals which significantly reduce their efforts, thus allowing them to target larger investment opportunities than they otherwise could afford alone.

\section{Acknowledgements}

We gratefully acknowledge Giusy Cannone (Italian Angels for Growth) for providing us with the dataset. The views expressed are those of the authors and are not necessarily shared by Italian Angels for Growth.

\section{Funding}

The author(s) received no financial support for the research, authorship and/or publication of this article.

\section{Notes}

1. The total business angel (BA) market has been estimated to be approximately the same size of the venture capital (VC) market, the US (European) VC market being at US\$18.3 billion (US\$5.3 billion) and the US (European) BA market at US\$17.7 billion (US\$5.6 billion) (Organisation for Economic Co-operation and Development (OECD), 2011). Carpentier and Suret (2015) report that between 2001 and 2013, US angels invested close to US $\$ 22$ billion per year in over 55,000 ventures. In Europe, data on the size and scale of the angel market are available for the United Kingdom, where it has been estimated that from 2000 to 2009 the number of angel deals increased by $41 \%$, the deal size increased by $148 \%$ and the total amount invested by BAs increased by $109 \%$ (Sohl, 2012).

2. The 'sweet spot' for Italian Angels for Growth (IAG) relates to early stage investments between $€ 300,000$ and $€ 800,000$. IAG is not specialized in a specific industry, but invests in any sector where there is at least one expert member. The actual industrial distribution of investments is reported in Table 1.

3. As a non-profit association, annual fees and voluntary donations are used to sustain the IAG staff, composed of two analysts, an investment manager and a managing director.

4. In some cases, IAG accepts members with a lower investment capability if they bring a unique expertise in industries with a strategic value for the organization.

5. For a detailed description of IAG investments, please refer to section 'The investments'.

6. Mason and Rogers (1997) argue that the 'investment fit' is generally considered by BAs in the prescreening stage, before the merits of the proposal are examined.

7. This probability is equal to $54 \%$ if we use median values of business proposals instead of mean values.

8. This probability is equal to $60 \%$ if we use median values of business proposals instead of mean values.

\section{References}

Baum J and Silverman B (2004) Picking winners or building them? Alliance, intellectual, and human capital as selection criteria in venture financing and performance of biotechnology startups. Journal of Business Venturing 19: 411-436.

Bian Y (1997) Bringing strong ties back in: Indirect connection, bridges, and job search in China. American Sociological Review 62: 355-385.

Brush CG, Edelman LF and Manolova TS (2012) Ready for funding? Entrepreneurial ventures and the pursuit of angel financing. Venture Capital: An International Journal of Entrepreneurial Finance 14(2-3): 111-129. 
Carpentier C and Suret JM (2015) Angel group members' decision process and rejection criteria: A longitudinal analysis. Journal of Business Venturing 30(6): 808-821.

Clark C (2008) The impact of entrepreneurs' oral 'pitch' presentation skills on business angels' initial screening investment decisions. Venture Capital: An International Journal of Entrepreneurial Finance 10(3): 257-279.

Collewaert V and Sapienza HJ (2014) How does angel investor-entrepreneur conflict affect venture innovation? It depends. Entrepreneurship Theory and Practice. Epub ahead print 29 August. DOI: 10.1111/ etap. 12131.

Colombo MG, Croce A and Murtinu S (2014) Ownership structure, horizontal agency costs and the performance of high-tech entrepreneurial firms. Small Business Economics 42(2): 265-282.

Croce A, Guerini M and Ughetto E (2016) Angel financing and the performance of high-tech start-ups. Journal of Small Business Management DOI: 10.1111/jsbm.12250.

Feeney L, Haines GH and Riding AL (1999) Private investors' investment criteria: Insights from qualitative data. Venture Capital: An International Journal of Entrepreneurial Finance 1: 121-145.

Fiet JO (1995) Reliance upon informants in the venture capital industry. Journal of Business Venturing 10(3): 195-223.

Haines GH Jr, Madill JJ and Riding AL (2003) Informal investment in Canada: Financing small business growth. Journal of Small Business and Entrepreneurship 16(3-4): 13-40.

Harrison RT and Mason CM (1999) Editorial: An overview of informal venture capital research. Venture Capital: An International Journal of Entrepreneurial Finance 1: 95-100.

Harrison RT and Mason CM (2002) Backing the horse or the jockey? Agency costs, information and the evaluation of risk by business angels. In: Frontiers of Entrepreneurship Research, pp. 393-403. Available at: http://eprints.gla.ac.uk/74983/

Harrison RT, Dibben MR and Mason CM (1997) The role of trust in the informal investor's investment decision. Entrepreneurship Theory and Practice 21(4): 63-81.

Harrison RT, Mason C and Robson P (2010) Determinants of long-distance investing by business angels in the UK. Entrepreneurship \& Regional Development 22(2): 113-137.

Haynie JM, Shepherd DA and McMullen JS (2009) An opportunity for me? The role of resources in opportunity evaluation decisions. Journal of Management Studies 46(3): 337-361.

Hellmann T and Thiele V (2015) Friends or foes? The interrelationship between angel and venture capital markets. Journal of Financial Economics 115(3): 639-653.

Hellmann T, Schure P and Vo D (2015) Angels and venture capitalists: Complements or substitutes? Said Business School Working Paper 2015-2. Available at: http://eureka.sbs.ox.ac.uk/5264/1/2015-2.pdf

Hsu DK, Haynie JM, Simmons SA, et al. (2014) What matters, matters differently: A conjoint analysis of the decision policies of angel and venture capital investors. Venture Capital: An International Journal of Entrepreneurial Finance 16: 1-25.

Kerr WR, Lerner J and Schoar A (2014) The consequences of entrepreneurial finance: Evidence from angel financings. Review of Financial Studies 27(1): 20-55.

Landström H (1998) Informal investors as entrepreneurs. Technovation 18(5): 321-333.

Madill J, Haines G and Riding A (2005) The role of angels in technology SMEs: A link to venture capital. Venture Capital: An International Journal of Entrepreneurial Finance 7: 107-129.

Mason CM and Botelho T (2016) The role of the exit in the initial screening of investment opportunities: The case of business angel syndicate gatekeepers. International Small Business Journal 34(2): 157-175.

Mason CM and Harrison RT (1996) Informal venture capital: A study of the investment process. The post-investment experience and investment performance. Entrepreneurship \& Regional Development 8: 105-125.

Mason CM and Harrison RT (1999) Why 'business angels' say no: A case study of opportunities rejected by an informal investor syndicate. International Small Business Journal 14(2): 35-51.

Mason CM and Harrison RT (2000) The size of the informal venture capital market in the United Kingdom. Small Business Economics 15: 137-148.

Mason CM and Harrison RT (2003) Auditioning for money: What do technology investors look for at the initial screening stage? Journal of Private Equity 6(2): 29-42. 
Mason CM and Rogers A (1997) The Business Angel's investment decision: An exploratory analysis. In: Deakins D, Jennings P and Mason C (eds) Small Firms: Entrepreneurship in the 1990s. London: Paul Chapman Publishing, pp. 29-46.

Mason CM and Stark M (2004) What do investors look for in a business plan? A comparison of the investment criteria of bankers, venture capitalists and venture capitalists. International Small Business Journal 22(3): 227-248.

Mason CM, Botelho T and Harrison RT (2013) The transformation of the business angel market: Evidence from Scotland. Working paper. Available at: http://ssrn.com/abstract=2306653

Maxwell A and Lévesque M (2014) Trustworthiness: A critical ingredient for entrepreneurs seeking investors. Entrepreneurship Theory and Practice 38(5): 1057-1080.

Maxwell A, Jeffrey S and Lévesque M (2011) Business angel early stage decision making. Journal of Business Venturing 26(2): 212-225.

Mitteness C, Baucus MS and Sudek R (2012a) Horse vs. Jockey? How stage of funding process and industry experience affect the evaluations of angel investors. Venture Capital: An International Journal of Entrepreneurial Finance 14(4): 241-267.

Mitteness C, Sudek R and Cardon MS (2012b) Angel investor characteristics that determine whether perceived passion leads to higher evaluations of funding potential. Journal of Business Venturing 27(5): 592-606.

Nofsinger RJ and Wang W (2011) Determinants of start-up firm external financing worldwide. Journal of Banking \& Finance 35: 2282-2294.

Organisation for Economic Co-operation and Development (OECD) (2011) Financing High-Growth Firms: The Role of Angel Investors. OECD Publishing. Available at: http://dx.doi.org/10.1787/9789264118782en (accessed 25 November 2014).

Parhankangas A and Ehrlich M (2014) How entrepreneurs seduce business angels: An impression management approach. Journal of Business Venturing 29: 543-564.

Paul S and Whittam G (2010) Business angel syndicates: An exploratory study of gatekeepers. Venture Capital: An International Journal of Entrepreneurial Finance 12(3): 241-256.

Paul S, Whittam G and Wyper J (2007) Towards a model of the business angel investment process. Venture Capital: An International Journal of Entrepreneurial Finance 9(2): 107-125.

Riding A, Maddill J and Haines G (2007) Investment decision making by business angels. In: Landström H (ed.) Handbook of Venture Capital. Cheltenham: Edward Elgar, pp. 332-346.

Smith DJ, Harrison R and Mason CM (2010) Experience, heuristics and learning: The angel investment process. Frontiers of Entrepreneurship Research 30(2). Available at: http://digitalknowledge.babson.edu/ fer/vol30/iss $2 / 3 /$

Sohl J (2012) The changing nature of the angel market. In: Landström H and Mason C (eds.), Handbook of Research on Venture Capital. Cheltenham: Edward Elgar, pp. 17-41.

Sørheim R (2003) The pre-investment behaviour of business angels: A social capital approach. Venture Capital: An International Journal of Entrepreneurial Finance 5(4): 337-364.

Van Osnabrugge M (2000) A comparison of business angel and venture capitalist investment procedures: An agency theory-based analysis. Venture Capital: An International Journal of Entrepreneurial Finance 2: 91-109.

Van Osnabrugge M and Robinson RJ (2000) Angel investing. San Francisco, CA: Jossey-Bass Publisher.

Wallnöfer M and Hacklin F (2013) The business model in entrepreneurial marketing: A communication perspective on business angels' opportunity interpretation. Industrial Marketing Management 42: 755-764.

Werth JC and Boeert P (2013) Co-investment networks of business angels and the performance of their startup investments. International Journal of Entrepreneurial Venturing 5(3): 240-256.

Wetzel WE (1983) Angels and informal risk capital. Sloan Management Review 24(4): 23-34.

Wiltbank R (2005) Investment practices and outcomes of informal venture investors. Venture Capital: An International Journal of Entrepreneurial Finance 7(4): 343-357.

\section{Author biographies}

Annalisa Croce is Assistant Professor at Politecnico di Milano. Her work mainly focuses in corporate finance and economics of innovation. She has published in several journals such as Journal of Business Venturing, 
Research Policy, Entrepreneurship Theory and Practice, Journal of Corporate Finance, Journal of Small Business Management, Review of Finance, European Financial Management and Small Business Economics among others.

Francesca Tenca is a PhD student in Management Engineering at Politecnico di Milano. Her main research interests concern business angels and crowdfunding financing.

Elisa Ughetto is Assistant Professor at Politecnico di Torino and Research Associate at BRICK, Real Collegio. Her work mainly focuses in corporate finance and economics of innovation. She has contributed articles to international refereed journals, such as Journal of Corporate Finance, Research Policy, Industrial and Corporate Change, Journal of Small Business Management, Small Business Economics, Technological Forecasting \& Social Change, Journal of Banking and Finance, Cambridge Journal of Economics, International Small Business Journal, R\&D Management, Regional Studies, The Manchester School, International Entrepreneurship and Management Journal, Journal of Business Research, International Business Review among others. 